AperTO - Archivio Istituzionale Open Access dell'Università di Torino

\title{
Aero-dispersed mutagenicity attributed to particulate and semi volatile phase in an urban environment
}

\section{This is the author's manuscript}

Original Citation:

Availability:

This version is available http://hdl.handle.net/2318/150871

since 2016-11-30T12:56:33Z

Published version:

DOI:10.1016/j.chemosphere.2014.12.033

Terms of use:

Open Access

Anyone can freely access the full text of works made available as "Open Access". Works made available under a Creative Commons license can be used according to the terms and conditions of said license. Use of all other works requires consent of the right holder (author or publisher) if not exempted from copyright protection by the applicable law. 
This Accepted Author Manuscript (AAM) is copyrighted and published by Elsevier. It is posted here by agreement between Elsevier and the University of Turin. Changes resulting from the publishing process - such as editing, corrections, structural formatting, and other quality control mechanisms - may not be reflected in this version of the text. The definitive version of the text was subsequently published in CHEMOSPHERE, 124 (-), 2015, 10.1016/j.chemosphere.2014.12.033.

You may download, copy and otherwise use the AAM for non-commercial purposes provided that your license is limited by the following restrictions:

(1) You may use this AAM for non-commercial purposes only under the terms of the CC-BY-NC-ND license.

(2) The integrity of the work and identification of the author, copyright owner, and publisher must be preserved in any copy.

(3) You must attribute this AAM in the following format: Creative Commons BY-NC-ND license (http://creativecommons.org/licenses/by-nc-nd/4.0/deed.en), 10.1016/j.chemosphere.2014.12.033

The publisher's version is available at:

http://linkinghub.elsevier.com/retrieve/pii/S0045653514014611

When citing, please refer to the published version.

Link to this full text:

http://hdl.handle.net/2318/150871 
TITLE page:

Aero-dispersed mutagenicity attributed to particulate and semi volatile phase in an urban environment.

Short running title:

Particulate and non-particulate mutagenicity in an urban environment

AUTHORS: Deborah Traversi ${ }^{1 *}$, Festa Evelina ${ }^{1}$, Cristina Pignata $^{1}$, Giorgio Gilli ${ }^{1}$

\section{AFFILIATIONS:}

$11{ }^{1}$ Department of Public Health and Pediatrics, University of Torino, piazza Polonia 94, 10126 Torino, Italy

*CORRESPONDING AUTHOR:

14 Deborah Traversi

15 tel +390116705822

16 fax +390116705874

17 Department of Public Health and Pediatrics, University of Torino, piazza Polonia 94, 10126 Torino, Italy 18 e-mail: deborah.traversi@unito.it

KEY WORDS: particulate matter, mutagenicity, , urban air pollution, gas phase pollution

\section{ABSTRACT}

23 Commonly the atmospheric pollution research is focussed on particulate indicators especially when

24 mutagenicity was studied. On the other hand the volatile and semi-volatile compounds no adsorbed on to the particles can be genotoxic and mutagenic. Moreover some mutagenic compounds, such as polycyclic aromatic hydrocarbons, are present both in the particulate and in the gas-phase in according to chemical conditions. This work is focussed on the assessing of the total mutagenicity shifting the gas-phase and 
particulate phase, during two seasons, in Turin. Two sampling sessions are conducted for total particulate matter and gas-phase pollutants. Moreover meteorological and usual air pollution monitoring data were collected at the same sampling station. The Salmonella assay using the strains TA98 and YG1021 was conducted on each organic extract. The mean level of total suspended particles, PM10 and PM2.5 were $73.63 \pm 26.94,42.85 \pm 26.75$ and $31.55 \pm 26.35 \mu \mathrm{g} / \mathrm{m}^{3}$. The observed mutagenicity was PM induced YG1021 > PM induced TA98 > PM induced TA98+S9 >> non-particle induced YG1021 > non-particle induced TA98 > non-particle induced TA98+S9. The multivariate regression is significant when we consider air pollution and meteorological indicators and chemical conditions as predictors.

\section{HIGHLIGHTS}

Both chemicals and meteo-chemical parameters can influence the mutagenicity of air pollution.

The gas phase and particulate phase mutagenicity can be different and affected by season.

40 The gas phase accounted for only $1 \%$ of the observed mutagenicity.

41 The particulate mutagenicity is approximately 5 -fold higher during winter.

The contribution of the nitro-derived compounds seems to be crucial.

\section{Introduction}

45 Air pollution is one of the most important worldwide health concerns (WHO-Europe, 2013). Particularly in the last 10 years, in both the US and Europe, new directives and regulations supporting more restrictive pollution limits were published (Krzyzanowski, 2008). However, the early effects of air pollution cannot be avoided, especially for the urban population (EEA, 2012). A recent Eurobarometer survey showed that European citizens are deeply concerned about the impact of air pollution and that more than $70 \%$ of the European population is worried that air pollution and air quality is worsening over time(EU, 2013). The

51 decision to designate 2013 as the Year of Air reflects both the economic seriousness of the problem but 52 also the impacts on humans. Approximately $3 \%$ of cardiopulmonary and $5 \%$ of lung cancer deaths are 53 attributable to particulate matter (PM) pollution worldwide (HEI, 2013), while the disease burden related 54 specifically to PM2.5 pollution accounts for approximately $3.1 \%$ of the global disability-adjusted life years 
(Lim et al., 2012).

56 The total suspended particulate (TSP) air pollution is widespread and consists of a mixture of solid and

57 liquid particles suspended in the air. The physical and chemical characteristics of TSP vary by site. Common chemical constituents of PM include sulphates, nitrates, ammonium and other inorganic ions, but also include organic carbon, crustal material, particle-bound water, metals, aromatic hydrocarbons such as polycyclic hydrocarbons and their nitrated, oxidised, sulphated forms (Claxton et al., 2004; Breysse et al.,

61 2013). Especially in urban polluted locations, the secondary particulates formed from precursor gases are the prevalent toxic agents. Particle accumulation and coagulation reactions in the atmosphere produce a fine fraction of particulate matter (PM2.5) that often constitutes more than fifty percent of the TSP (Dimitriou and Kassomenos, 2013). The emitted chemicals, the dispersion conditions, and physical parameters such as humidity and temperature (Zhang et al., 2012) can all influence particle formation. A large number of studies provide evidence of a correlation between both for short term and long-term exposure to PM pollution and health effects such as morbidity and mortality from cardiovascular and respiratory diseases, as well as from lung cancer (Krzyzanowski, 2008). At the end of 2013, outdoor air pollution and its major component, outdoor particulate matter were classified as carcinogenic for humans (1 Group) (Loomis et al., 2013). Many mutagenic and genotoxic compounds are present in air pollution, and the effects are widely known and reviewed (de Kok et al., 2006; Claxton and Woodall, 2007a; Valavanidis et al., 2008; DeMarini, 2013). The finest air pollution fractions, PM10 (particles with a diameter of less than $10 \mu \mathrm{m}$ ) and PM2.5 (particles with a diameter of less than $2.5 \mu \mathrm{m}$ ) show greater genotoxicity (Claxton et al., 2004), while the ultrafine particles (particles having a diameter of less than $0.1 \mu \mathrm{m}$ ) are the subject of in-depth analyses (Hoek et al., 2010; Kovats et al., 2013). The studies conducted using in vivo and in vitro models show the induction of mutations and genotoxic effects. However, non-genotoxic effects also occur and various studies focused on the epigenetic effects of the ambient particles (Ji and Hershey, 2012). Among the typical air pollution chemicals, Polyciclic Aromatic Hydrocarbons PAHs have a relevant role in air pollution toxicity. These compounds are reactive in the atmosphere and primarily form oxidised products, the most notable being oxy-derivatives (mostly quinones) and nitrated compounds (Kim et al., 2013). Some 
of these compounds, such as benzo(a)pyrene and 6-ditrochrysene and the 7,12-

dimethylbenz(a)anthracene, are also present in primary emissions. Benzo(a)pyrene is the reference compound for the carcinogenic relative potency factor, while others previously cite PAHs as having a carcinogenic factor of 10 and 64, respectively. Also among the secondary PAHs are compounds with high carcinogenic relative potency factors such as benz(j)aceanthrylene (60) and 1,6-dinitropyrene (10) (ATSDR, 1995). The historic list of 16 USEPA priority PAHs is an important source of information, but was developed when knowledge of the relative toxicity of PAH congeners was more limited than at present. As such, it is useful as reference for monitoring but limited for the assessment of human health risks attributable to air PAH mixture exposition (Yang et al., 2007).

Vapor-particle partitioning of mutagens can be quantified using the gas-particle-partitioning coefficient for each compound. This coefficient is influenced by both the adsorption and absorption processes and is strongly temperature dependent (Albinet et al., 2008). Moreover, volatile and semi-volatile organic compounds associated with particulate matter can be influenced by heterogeneous photochemical reactions in the atmosphere (Fraser et al., 2000; Xie et al., 2013). Our typical samplings were conducted using standard methods that are affected by relevant limits (Liu et al., 2007; Forbes et al., 2012).

The aim of this work is to assess the mutagenicity of particulate and not-particulate air pollution and to determine the effects of seasonality and the contribution of nitro-compounds to the mutagenic effects in an urban environment.

\section{Materials and methods}

\section{$2.1 \quad$ Sampling}

Sampling was performed from 20 November to 22 December 2009 for the winter period and from 4 May to 4 June 2010 for the spring period at a meteorological-chemical station of the Environmental Protection Regional Agency (Piedmont A.R.P.A.) located at Torino, in the northwest of the Padana Plain, Italy. The sampling site, called Lingotto, was located outdoors in a small green area within an enclosed zone classified as urban background (ARPA Piemonte, 2010). Turin has 872,367 inhabitants and a population density of approximately 7,000 inhabitants per $\mathrm{km}^{2}$; thus, the pressure on the territory that is associated with human 
activity is very high (ISTAT, 2012). Moreover, the climate and topographical characteristics of the area

110 contribute to critical air pollution (Poncino et al., 2009; Eeftens et al., 2012). The Total Suspended Particles

111 (TSP) were collected on glass micro-fibre filters (Type Fiberfilm T60A20, 150 mm, SKC, 863 Valley View Road

112 Eighty Four, PA 15330, USA) and micro-pollutants were collected in Polyurethane Foam (PUF) Sorbent

113 Tubes (SKC, 226-131 Valley View Road Eighty Four, PA 15330, USA) using an AirFlowPuf Sampler and

114 conforming with the US EPA methods TO-4A, TO-9A, TO13A, ASTM D-6209 and ISO-12884, ISO-16362

115 (Analitica Strumenti Samplers, via degli Abeti 14461100 Pesaro, Italy).

116 The TSP were collected on glass fibre filters, and the polyurethane foam (PUF) cartridge was placed in series

117 after the glass fibre filter. The volatile compounds, which were not trapped on the filter, were retained in

118 the PUF cartridge.

119 The sampling flow was electronically controlled to be $250 \mathrm{~L} / \mathrm{min}$. Each sampling duration was controlled by

120 a timer that was accurate to \pm 15 min over a 48-hour sampling period. The exact flow rate was calculated

121 daily and corrected for variations in atmospheric pressure and actual differential pressure across the filter.

122 The filters were conditioned for $48 \mathrm{~h}$ and were weighed using an analytical balance $( \pm 10 \mu \mathrm{g})$ before and

123 after sampling to calculate the mass of the TSP trapped on the filter. The procedures were conducted

124 according to the European Committee for Standardization. Additionally, , the PUF had been pre-cleaned by

$12524 \mathrm{~h}$ Soxhlet extractions using acetone.

\section{$127 \quad 2.2 \quad$ Extraction and mutagenicity assays}

128 Each sample was extracted with acetone in a Soxhlet apparatus for a minimum of 80 cycles. The samples

129 were dried in a Rotavapor instrument, and suspended in dimethyl sulfoxide (DMSO) to obtain an equivalent

130 concentration of $0.1 \mathrm{~m}^{3}$ of sampled air per $\mu$ l of solution. The mutagenicity assay was conducted as

131 previously described (Maron and Ames, 1983; Traversi et al., 2009). Defined amounts of organic extract

132 were tested to generate a dose-response curve $\left(2,5,10,20,30\right.$ air equivalent $\mathrm{m}^{3}$ for the TSP extracts and

$13310,20,30,50,100$ air equivalent $\mathrm{m}^{3}$ for the PUF extracts). The slope of the dose-response curve

134 (revertants $/ \mathrm{m}^{3}$ ) was calculated by the least squares linear regression beginning at the first linear portion of 135 the dose-response curve (Traversi et al., 2011). All experiments were performed in triplicate using at least 
136 three doses. The results are expressed as net revertants per cubic metre $\left(\mathrm{rev} / \mathrm{m}^{3}\right)$ (the total revertants 137 minus the spontaneous revertants) and were calculated using the dose-response curve (Cassoni et al., 138 2004; Claxton et al., 2004). The mutagenic activity of the airborne particulate extracts was determined 139 using the Salmonella typhimurium strain TA98, with and without S9 mix, as well as the YG1021 strain.

140 YG1021 is a 'classical' nitroreductase-overproducing strain obtained by cloning the nitroreductase gene of 141 S. typhimurium TA1538 into the pBR322 vector and introducing the recombinant plasmid into TA98 142 (Josephy et al., 1997). YG1021 has a nitrofurazone reductase activity more than 50 times higher than the 143 original TA98 strain, permitting the efficient detection of mutagenic nitroarenes. The mean number of 144 spontaneous revertants, obtained during a 10 bioassay series, one every two samplings, was $16 \pm 4$ for 145 TA98, $21 \pm 1$ for TA98+S9 and $23 \pm 5$ for YG1021. The genotype of each tester strain was routinely 146 confirmed. In each assay session, positive and negative controls were included. Moreover, the known 147 mutagen 2-nitrofluorene ( $1 \mu \mathrm{g} /$ plate) was tested in each assay as a positive control for the strains TA98 and 148 YG1021 while amminofluorene (1 $\mu \mathrm{g} /$ plate) was used as a positive control for the TA98 strain in presence of 149 S9 mix.

\section{$151 \quad 2.3 \quad$ Chemicals and inhalable particles data}

Chemical data and inhalable particles data (PM10 and PM2.5) were extracted from a specialised database provided by the Regional System for the real-time monitoring of Air Quality, AriaWeb (ARPA Piemonte, 2014). The data were obtained for the same day as our sampling and for the same sampling station. For example, the NOx data represent a monthly mean of hourly data collected using the standard monitoring method EN 14211:2005 (2008/50/EC, annex VI, section B). All the adopted methods conform to the directive and were validated before being published in the AriaWeb database (ARPA Piemonte, 2014).

\section{$2.4 \quad$ Statistics}

161 The seasons were designated as winter for the first sampling session (November and December) and as 162 spring for the second sampling session (May and June). The statistical analyses were performed using the 
SPSS Package, version 21.0. In particular we applied: (1) a log transformation of non-normally distributed data, (2) the Spearman rank-order correlation coefficient to assess relationships between variables, (3) a Wilcoxon-Mann- Whitney test to compare means. The mean differences and correlations were considered significant if $p<0.05$.

\section{Results}

\subsection{Gravimetric analysis}

The descriptive analysis of the collected data is shown in Table 1. The gravimetric data showed that, on average, meanly the TSP proportion in the samples was 58\% PM10 and 43\% PM2.5. Moreover, during the high pollution period in winter, these proportions increased up to $70 \%$ and $61 \%$, with a PM2.5/PM10 ratio equal to 0.87 . Moreover, Figure 1 highlights the marked seasonal differences for all three particulate indicators, with the mean comparison between winter and spring means for TSP, PM10 and PM2.5 being significant $(p<0.01)$. The mean reduction in TSP in the spring with respect to winter was $30 \%$, with mean reductions of $68 \%$ for PM10 and $82 \%$ for PM2.5. The mean temperature differences between sampling seasons was significantly different by $(p<0.01)$ with the mean winter temperature being $2.95 \pm 4.09^{\circ} \mathrm{C}$ and the mean spring temperature being $16.55 \pm 4.20^{\circ} \mathrm{C}$. However neither the average humidity nor the wind speed were significantly different, with $0.73 \%$ humidity during the winter vs. $0.64 \%$ spring $(p>0.05)$ and , an average wind speed in both seasons of approximately $10 \mathrm{~m} / \mathrm{s}$ (Table 1).

\subsection{Mutagenicity}

The mutagenicity tests show a significantly elevated of net revertants per unit of exposure (air equivalent $\mathrm{m}^{3}$ ) respect to the negative control. An elevated number of net revertants (250) was recorded at the highest test doses for the winter TSP extracts in the YG1021 strain, while the mutagenicity of the PUF extracts was markedly lower (Table 1). The PUF extracts contribute only about $2 \%$ to the total mutagenicity. As figure $\mathbf{2}$ also shows, the mutagenicity of the samples, expressed as net revertants, from higher to the lower was PM induced YG1021 > PM induced TA98 > PM induced TA98+S9 >> non-particle induced YG1021 > non-particle induced TA98 > non-particle induced TA98+S9. Moreover, the seasonal 
trend is clearly evident and significant only for particulate-induced mutagenicity (YG1021 p<0.01; TA98

$191 p<0.01 ;$ TA98+S9 $p<0.01)$. The mutagenicity of the spring TSP samples is less than $10 \%$ of the mutagenicity 192 recorded for the winter samples in all the strains.

193 The higher mutagenicity of the winter particles was confirmed also adjusting the data for particles mass unit (Figure 3), highlighting the worse quality of the particles- in terms of mutagen presence - and not only the higher level of aero-dispersed pollution for each volume unit. Among the chemicals variability we observed a not so great changeability during the year for PAHs and metals, observing a difference due to seasonality. More variability is instead observable for $\mathrm{NO}_{\mathrm{x}}$ and ozone, however also in this case the levels are clearly affected by seasonality (with highest value recoding in winter with the ozone exception )(table 1). Table 2 showed the correlations between variables. Only the variables for which at least one correlation with mutagenicity is significant was included, the not particles induced mutagenicity was however included for its experimental origin, favoring the mutagenicity results comparison.

203 As presented, the mutagenicity attributed to the non-particle phase was not influenced by the 204 environmental temperature or wind speed and, furthermore, does not correlate with the mutagenicity of 205 the particle phase. Additionally, the chemical parameters did not correlate with the minimal mutagenic 206 effects of the non-particle phase (table 2).

207 In contrast, the temperature and wind speed significantly inversely correlated with the TSP levels and to 208 mutagenicity of this mixture. The TSP level correlated with mutagenicity and, in particular, this correlation 209 showed a higher Spearman's rho for TA98 strain, with and without the addition of the S9 mixture. The 210 results of the mutagenicity assays conducted using the TSP extracts all correlate with each other (Table 2). 211 Among the chemical parameters, the TSP mutagenicity correlates with the presence of nitrogen oxides and, 212 in particular, this relationship is more marked for the nitrogen monoxides. The ozone levels inversely and 213 significantly correlate with the TSP mutagenicity. The cadmium and nickel levels significantly correlate with 214 direct mutagenicity (i.e., without the introduction of the metabolic activation). The TSP mutagenicity 215 correlates to the concentration of the finest fraction of the particulate matter and, in particular, there is a 216 better correlation with the PM10 fraction in the TA98 strain with and without metabolic activation. A 
217 significant correlation is not observed between benzo(a)pyrene or benzo(a)antracene and mutagenicity but

218 there was a high correlation between PAHs and with metals $(0.929 \mathrm{p}<0.01)$ due probably mainly to the

219 same seasonality.

220 Among the meteo climatic variables the temperature showed the high influence to the particulate pollution

221 and associated mutagenicity, moreover this physical parameter is not significantly correlated to the wind

222 that also showed an influence on the particulate pollution dispersion but not on the $\mathrm{NO}_{\mathrm{x}}$ and ozone levels.

223 The humidity during the sampling showed a quite constant level so in this study we can't observe an

224 influence on the pollution level.

225 The $\mathrm{NO}_{x}$, in particular NO, among the chemicals correlated with particulate pollution and associated 226 mutagenicity, moreover with PAHs, cadmium and nickel. This result was similar to those previously 227 observed in other studies (Du Four et al., 2004; Du Four et al., 2005).

\section{Discussion}

230 In our study, the inhalable fraction and the high-risk inhalable fraction represented a very high proportion 231 of the TSP, highlighting a human health hazard comparable to that estimated for urban sites. The observed 232 pollution levels are significantly higher than both the WHO guidelines (Krzyzanowski, 2008) and the EU 233 regulations 2008/50/CE. In addition, critical particle concentrations are present particularly during the 234 winter and especially for PM2.5. Recently, the IARC classified outdoor pollution and particulate matter, as 235 its major component, as carcinogenic for humans (Loomis et al., 2013). Consequently, reducing air pollution 236 and particle matter to the lowest amount possible is becoming a marked priority.

237 Particulate matter clearly contributed to the overall mutagenicity (Figure 2). This observation confirmed 238 the evidence of other studies where PM total air toxicity and genotoxicity was higher than the gas phase 239 fraction. In particular, PM1 was responsible for approximately $80 \%$ of the observed effects at various 240 sampling localities (Novak et al., 2014), and the fine particles generally showed higher mutagenicity 241 (Claxton et al., 2004; Claxton and Woodall, 2007b; Lemos et al., 2012). The gas phase mutagenicity was very 242 low and often indeterminable, with the exception of particular sampling sites such as industrial sites (Du 243 Four et al., 2005) and exhaust emissions from gasoline- and diesel-powered passengers cars (Pohjola et al., 
2003a; Pohjola et al., 2003b). The contribution of the gas phase with respect to the particulate phase seems

245 to be higher during summer and related to the major PAHs content (Du Four et al., 2004; Kennedy et al., 246 2010). In the present study, the contribution of the gas phase with respect to the particulate phase is 247 relative; in summer the particulate phase mutagenicity is reduced while the gas phase mutagenicity 248 remains quite constant. It is supposable that this level of mutagenicity is not imputable to climatic or 249 chemical stress condition and it indicates probably a background mutagenicity level hardly to avoid.

250 The benzo(a)pyrene concentration was higher during the winter than summer and higher than the WHO 251 guide line value of $0.12 \mathrm{ng} / \mathrm{m}^{3}$ (Krzyzanowski, 2008; WHO-Europe, 2013). As widely observed, the PAHs are 252 generally higher in the gas phase (Lemos et al., 2012), however, this fraction is less genotoxic and 253 mutagenic, and thus PAH concentration explains only a small part of air pollution toxicity. Moreover, PAHs 254 can react with nitrogen oxides, generating more genotoxic and mutagenic compounds (Albinet et al., 2008). 255 The contribution of the nitro-derivate compounds to the overall mutagenicity, as assessed by comparing 256 the number of Salmonella YG1021 net revertants to the strain without the modified nitro-reductase 257 activity, was marked. The ratio of the net revertants observed in the TA98 and YG1021 strains is 258 approximately 1:2, during both summer and winter. This observation is widely confirmed by other studies 259 (Ramos de Rainho et al.; Traversi et al., 2009). Moreover the direct mutagens action is higher than indirect 260 mutagens as highlighted by the ratio of the net revertants observed in the TA98 and TA98+S9 that is 261 approximately of 1:1.7.

262 Air pollution and its major components have a marked seasonality, and the toxic content in the gas phase 263 and particulate phase can vary based upon the meteo-climatic conditions (Albinet et al., 2008). In 264 particular, more nitro-derived compounds can be present in the particulates during winter, thus enhancing 265 the genotoxic and mutagenic properties.

\section{Conclusions}

268 By combining data on meteo-climatic conditions, various air pollution indicators and mutagenicity assays 269 we produced an evaluation of particulate and non-particulate air pollution in Turin during different season.. 270 We present the following results: 
- In the present study, the mutagenicity of the gas phase sampled by PUF method is practically negligible with respect to the mutagenicity of the particulate phase. The gas phase accounted for only $1 \%$ of the observed mutagenicity.

- The mutagenicity of the non-particulate phase remained constant during the summer and winter, while the particulate mutagenicity is approximately 5 -fold higher during winter when the finest fraction of the PM increases. impact of air pollution. (local funds ex-60\% 2012) and the Piedmont Region (Italy) in the field of health projects.

\section{Conflict of interest statement}

The authors have nothing to declare. Funding source: this study was co-funded by the University of Turin

\section{Acknowledgements}


297 The authors thank the Environmental Protection Agency of Piedmont, especially dott. F. Lollobrigida and

298 dott.ssa M. Maringo, for their collaboration in the sample collection and Dr. T. Nohmi of the National

299 Institute of Hygienic Sciences of Tokyo for the S. typhimurium YG1021 and TA98NR strains.

8 List of abbreviations:

302 PAHs Polycyclic Aromatic Hydrocarbons

303 PCR Polymerase Chain Reaction

304 TSP Total Suspended Particles

305 PM Particulate matter

306 PM10 Particulate matter with an aerodynamic diameter $<10 \mu \mathrm{m}$

307 PM2.5 Particulate matter with an aerodynamic diameter $<2.5 \mu \mathrm{m}$

309 Table legends:

310 Table 1 -Descriptive analysis on 20 total measurements for each parameter are showed median and first

311 and third quartiles .

313 Table 2 -Spearman's correlation between the mutagenicity, gravimetric, chemical and meteorological

314 variables ${ }^{1}$ rho $=-0.436, p=0.054$

316 Figure legends:

317 Figure 1 - Mean and standard deviation of TSP, PM10 and PM2.5 levels recorded during the winter and 318 spring sampling sessions.

319 Figure 2 - Total mutagenicity, subdivided into gas phase and particulate phase, recorded for the winter and 320 summer samples with metabolically different strains.

321 Figure 3 - Net revertants expressed as unit mass of total suspended particulate for the different strain and 322 the different seasons. 
Albinet, A., Leoz-Garziandia, E., Budzinski, H., Villenave, E., Jaffrezo, J.L., 2008. Nitrated and oxygenated derivatives of polycyclic aromatic hydrocarbons in the ambient air of two French alpine valleys - Part 1: Concentrations, sources and gas/particle partitioning. Atmospheric Environment 42, 43-54.

ARPA Piemonte, P.d.T., 2010. Uno sguardo all'aria 2010. Relazione annuale sui dati rilevati dalla rete provinciale di monitoraggio della qualità dell'aria - Anno 2010. Provincia di Torino, Torino.

ARPA Piemonte, S.P., CSI Piemonte, 2014. ARIAWEB - Sistema Regionale di Rilevamento della Qualità dell'Aria della Regione Piemonte.

ATSDR, 1995. Toxicological Profile for Polycyclic Aromatic Hydrocarbons (PAHs). In: profile, A.t. (Ed.).

Breysse, P.N., Delfino, R.J., Dominici, F., Elder, A.C.P., Frampton, M.W., Froines, J.R., Geyh, A.S., Godleski, J.J., Gold, D.R., Hopke, P.K., Koutrakis, P., Li, N., Oberdorster, G., Pinkerton, K.E., Samet, J.M., Utell, M.J., Wexler, A.S., 2013. US EPA particulate matter research centers: summary of research results for 2005-2011. Air Quality Atmosphere and Health 6, 333-355.

Cassoni, F., Bocchi, C., Martino, A., Pinto, G., Fontana, F., Buschini, A., 2004. The Salmonella mutagenicity of urban airborne particulate matter (PM2.5) from eight sites of the Emilia-Romagna regional monitoring network (Italy). Sci Total Environ 324, 79-90.

Claxton, L.D., Matthews, P.P., Warren, S.H., 2004. The genotoxicity of ambient outdoor air, a review: Salmonella mutagenicity. Mutat Res 567, 347-399.

Claxton, L.D., Woodall, G.M., 2007a. A review of the mutagenicity and rodent carcinogenicity of ambient air. Mutation Research-Reviews in Mutation Research 636, 36-94.

Claxton, L.D., Woodall, G.M., Jr., 2007b. A review of the mutagenicity and rodent carcinogenicity of ambient air. Mutat Res 636, 36-94.

de Kok, T.M.C.M., Driece, H.A.L., Hogervorst, J.G.F., Briede, J.J., 2006. Toxicological assessment of ambient and traffic-related particulate matter: A review of recent studies. Mutation Research-Reviews in Mutation Research 613, 103-122.

DeMarini, D.M., 2013. Genotoxicity biomarkers associated with exposure to traffic and near-road atmospheres: a review. Mutagenesis 28, 485-505.

Dimitriou, K., Kassomenos, P., 2013. The fine and coarse particulate matter at four major Mediterranean cities: local and regional sources. Theoretical and Applied Climatology 114, 375-391.

Du Four, V.A., Janssen, C.R., Brits, E., Van Larebeke, N., 2005. Genotoxic and mutagenic activity of environmental air samples from different rural, urban and industrial sites in Flanders, Belgium. Mutation Research-Genetic Toxicology and Environmental Mutagenesis 588, 106-117.

Du Four, V.A., Van Larebeke, N., Janssen, C.R., 2004. Genotoxic and mutagenic activity of environmental air samples in Flanders, Belgium. Mutation Research-Genetic Toxicology and Environmental Mutagenesis 558, 155-167.

EEA, 2012. European Environmental Agency - Air quality in Europe - 2012 report Office for Official Publications of the European Union, Copenhagen.

Eeftens, M., Tsai, M.Y., Ampe, C., Anwander, B., Beelen, R., Bellander, T., Cesaroni, G., Cirach, M., Cyrys, J., de Hoogh, K., De Nazelle, A., de Vocht, F., Declercq, C., Dedele, A., Eriksen, K., Galassi, C., Grazuleviciene, R., Grivas, G., Heinrich, J., Hoffmann, B., lakovides, M., Ineichen, A., Katsouyanni, K., Korek, M., Kramer, U., Kuhlbusch, T., Lanki, T., Madsen, C., Meliefste, K., Molter, A., Mosler, G., Nieuwenhuijsen, M., Oldenwening, M., Pennanen, A., Probst-Hensch, N., Quass, U., Raaschou-Nielsen, O., Ranzi, A., Stephanou, E., Sugiri, D., Udvardy, O., Vaskoevi, E., Weinmayr, G., Brunekreef, B., Hoek, G., 2012. Spatial variation of PM2.5, PM10, 
PM2.5 absorbance and PMcoarse concentrations between and within 20 European study areas and the relationship with NO2 - Results of the ESCAPE project. Atmospheric Environment 62, 303-317.

EU, E.C., 2013. Attitudes of Europeans towards air quality. In: Environment, D.-G.f.t. (Ed.). Flash Eurobarometer 360

Forbes, P.B.C., Karg, E.W., Zimmermann, R., Rohwer, E.R., 2012. The use of multi-channel silicone rubber traps as denuders for polycyclic aromatic hydrocarbons. Analytica Chimica Acta 730, 71-79.

Fraser, M.P., Kleeman, M.J., Schauer, J.J., Cass, G.R., 2000. Modeling the atmospheric concentrations of individual gas-phase and particle-phase organic compounds. Environmental Science \& Technology 34, $1302-1312$.

HEI, E.C.E., 2013. Understanding the Health Effects of Air Pollution: Recent Advances to Inform EU Policies Brussels, Belgium Auditorium, Madou Tower, Place Madou

Hoek, G., Boogaard, H., Knol, A., De Hartog, J., Slottje, P., Ayres, J.G., Borm, P., Brunekreef, B., Donaldson, K., Forastiere, F., Holgate, S., Kreyling, W.G., Nemery, B., Pekkanen, J., Stone, V., Wichmann, H.E., Van der Sluijs, J., 2010. Concentration Response Functions for Ultrafine Particles and All-Cause Mortality and Hospital Admissions: Results of a European Expert Panel Elicitation. Environmental Science \& Technology 44, 476-482.

ISTAT, $2012.15^{\circ}$ Censimento generale della popolazione e delle abitazioni

Ji, H., Hershey, G.K.K., 2012. Genetic and epigenetic influence on the response to environmental particulate matter. Journal of Allergy and Clinical Immunology 129, 33-41.

Josephy, P.D., Gruz, P., Nohmi, T., 1997. Recent advances in the construction of bacterial genotoxicity assays. Mutat Res 386, 1-23.

Kennedy, K., Macova, M., Bartkow, M.E., Hawker, D.W., Zhao, B., Denison, M.S., Mueller, J.F., 2010. Effect based monitoring of seasonal ambient air exposures in Australia sampled by PUF passive air samplers.

Kim, K.H., Jahan, S.A., Kabir, E., Brown, R.J., 2013. A review of airborne polycyclic aromatic hydrocarbons (PAHs) and their human health effects. Environ Int 60, 71-80.

Kovats, N., Acs, A., Ferincz, A., Kovacs, A., Horvath, E., Kakasi, B., Jancsek-Turoczi, B., Gelencser, A., 2013. Ecotoxicity and genotoxicity assessment of exhaust particulates from diesel-powered buses. Environmental Monitoring and Assessment 185, 8707-8713.

Krzyzanowski, M., 2008. WHO Air Quality Guidelines for Europe. J Toxicol Environ Health A 71, 47-50.

Lemos, A.T., Coronas, M.V., Rocha, J.A.V., Vargas, V.M.F., 2012. Mutagenicity of particulate matter fractions in areas under the impact of urban and industrial activities. Chemosphere 89, 1126-1134.

Lim, S.S., Vos, T., Flaxman, A.D., Danaei, G., Shibuya, K., Adair-Rohani, H., Amann, M., Anderson, H.R., Andrews, K.G., Aryee, M., Atkinson, C., Bacchus, L.J., Bahalim, A.N., Balakrishnan, K., Balmes, J., BarkerCollo, S., Baxter, A., Bell, M.L., Blore, J.D., Blyth, F., Bonner, C., Borges, G., Bourne, R., Boussinesq, M., Brauer, M., Brooks, P., Bruce, N.G., Brunekreef, B., Bryan-Hancock, C., Bucello, C., Buchbinder, R., Bull, F., Burnett, R.T., Byers, T.E., Calabria, B., Carapetis, J., Carnahan, E., Chafe, Z., Charlson, F., Chen, H.L., Chen, J.S., Cheng, A.T.A., Child, J.C., Cohen, A., Colson, K.E., Cowie, B.C., Darby, S., Darling, S., Davis, A., Degenhardt, L., Dentener, F., Des Jarlais, D.C., Devries, K., Dherani, M., Ding, E.L., Dorsey, E.R., Driscoll, T., Edmond, K., Ali, S.E., Engell, R.E., Erwin, P.J., Fahimi, S., Falder, G., Farzadfar, F., Ferrari, A., Finucane, M.M., Flaxman, S., Fowkes, F.G.R., Freedman, G., Freeman, M.K., Gakidou, E., Ghosh, S., Giovannucci, E., Gmel, G., Graham, K., Grainger, R., Grant, B., Gunnell, D., Gutierrez, H.R., Hall, W., Hoek, H.W., Hogan, A., Hosgood, H.D., Hoy, D., Hu, H., Hubbell, B.J., Hutchings, S.J., Ibeanusi, S.E., Jacklyn, G.L., Jasrasaria, R., Jonas, J.B., Kan, H.D., Kanis, J.A., Kassebaum, N., Kawakami, N., Khang, Y.H., Khatibzadeh, S., Khoo, J.P., Kok, C., Laden, F., Lalloo, R., Lan, Q., Lathlean, T., Leasher, J.L., Leigh, J., Li, Y., Lin, J.K., Lipshultz, S.E., London, S., Lozano, R., Lu, Y., Mak, J., Malekzadeh, R., Mallinger, L., Marcenes, W., March, L., Marks, R., Martin, R., McGale, P., 

Mokdad, A.A., Morawska, L., Mozaffarian, D., Murphy, T., Naghavi, M., Neal, B., Nelson, P.K., Nolla, J.M., Norman, R., Olives, C., Omer, S.B., Orchard, J., Osborne, R., Ostro, B., Page, A., Pandey, K.D., Parry, C.D.H., Passmore, E., Patra, J., Pearce, N., Pelizzari, P.M., Petzold, M., Phillips, M.R., Pope, D., Pope, C.A., Powles, J., Rao, M., Razavi, H., Rehfuess, E.A., Rehm, J.T., Ritz, B., Rivara, F.P., Roberts, T., Robinson, C., RodriguezPortales, J.A., Romieu, I., Room, R., Rosenfeld, L.C., Roy, A., Rushton, L., Salomon, J.A., Sampson, U., Sanchez-Riera, L., Sanman, E., Sapkota, A., Seedat, S., Shi, P.L., Shield, K., Shivakoti, R., Singh, G.M., Sleet, D.A., Smith, E., Smith, K.R., Stapelberg, N.J.C., Steenland, K., Stockl, H., Stovner, L.J., Straif, K., Straney, L., Thurston, G.D., Tran, J.H., Van Dingenen, R., van Donkelaar, A., Veerman, J.L., Vijayakumar, L., Weintraub, R., Weissman, M.M., White, R.A., Whiteford, H., Wiersma, S.T., Wilkinson, J.D., Williams, H.C., Williams, W., Wilson, N., Woolf, A.D., Yip, P., Zielinski, J.M., Lopez, A.D., Murray, C.J.L., Ezzati, M., 2012. A comparative risk assessment of burden of disease and injury attributable to 67 risk factors and risk factor clusters in 21 regions, 1990-2010: a systematic analysis for the Global Burden of Disease Study 2010. Lancet 380, 22242260.

Liu, S.Z., Tao, S., Liu, W.X., Liu, Y.N., Dou, H., Zhao, J.Y., Wang, L.G., Wang, J.F., Tian, Z.F., Gao, Y., 2007.

Atmospheric polycyclic aromatic hydrocarbons in north China: A winter-time study. Environmental Science \& Technology $41,8256-8261$.

Loomis, D., Grosse, Y., Lauby-Secretan, B., El Ghissassi, F., Bouvard, V., Benbrahim-Tallaa, L., Guha, N., Baan, 1263.

Maron, D.M., Ames, B.N., 1983. Revised methods for the Salmonella mutagenicity test. Mutat Res 113, 173215.

Novak, J., Hilscherova, K., Landlova, L., Cupr, P., Kohut, L., Giesy, J.P., Klanova, J., 2014. Composition and effects of inhalable size fractions of atmospheric aerosols in the polluted atmosphere. Part II. In vitro biological potencies. Environment International 63, 64-70.

Pohjola, S.K., Lappi, M., Honkanen, M., Rantanen, L., Savela, K., 2003a. DNA binding of polycyclic aromatic hydrocarbons in a human bronchial epithelial cell line treated with diesel and gasoline particulate extracts and benzo[a]pyrene. Mutagenesis 18, 429-438.

Pohjola, S.K., Lappi, M., Honkanen, M., Savela, K., 2003b. Comparison of mutagenicity and calf thymus DNA adducts formed by the particulate and semivolatile fractions of vehicle exhausts. Environmental and Molecular Mutagenesis 42, 26-36.

Poncino, S., Bande, S., Muraro, M., 2009. Meteo-diffusive analysis: a case study of Turin. Epidemiologia \& Prevenzione 33, 27-33.

Ramos de Rainho, C., Machado Correa, S., Luiz Mazzei, J., Alessandra Fortes Aiub, C., Felzenszwalb, I., Genotoxicity of polycyclic aromatic hydrocarbons and nitro-derived in respirable airborne particulate matter collected from urban areas of Rio de Janeiro (Brazil). Biomed Res Int 2013, 765352.

Traversi, D., Degan, R., De Marco, R., Gilli, G., Pignata, C., Villani, S., Bono, R., 2009. Mutagenic properties of PM2.5 urban pollution in the Northern Italy: The nitro-compounds contribution. Environment International 35, 905-910.

Traversi, D., Schiliro, T., Degan, R., Pignata, C., Alessandria, L., Gilli, G., 2011. Involvement of nitrocompounds in the mutagenicity of urban Pm2.5 and Pm10 in Turin. Mutation Research-Genetic Toxicology and Environmental Mutagenesis 726, 54-59.

Valavanidis, A., Fiotakis, K., Vlachogianni, T., 2008. Airborne Particulate Matter and Human Health: Toxicological Assessment and Importance of Size and Composition of Particles for Oxidative Damage and Carcinogenic Mechanisms. Journal of Environmental Science and Health Part C-Environmental Carcinogenesis \& Ecotoxicology Reviews 26, 339-362. 
459 WHO-Europe, 2013. Review of evidence on health aspects of air pollution - Technical Report - REVIHAAP 460 Project

461 Xie, M., Barsanti, K.C., Hannigan, M.P., Dutton, S.J., Vedal, S., 2013. Positive matrix factorization of PM2.5 462 eliminating the effects of gas/particle partitioning of semivolatile organic compounds. Atmospheric 463 Chemistry and Physics 13, 7381-7393.

464 Yang, H.H., Chien, S.M., Cheng, M.T., Peng, C.Y., 2007. Comparative study of regulated and unregulated air 465 pollutant emissions before and after conversion of automobiles from gasoline power to liquefied 466 petroleum gas/gasoline dual-fuel retrofits. Environmental Science \& Technology 41, 8471-8476.

467 Zhang, Y.W., Gu, Z.L., Cheng, Y., Shen, Z.X., Dong, J.G., Lee, S.C., 2012. Measurement of Diurnal Variations of 468 PM2.5 Mass Concentrations and Factors Affecting Pollutant Dispersion in Urban Street Canyons under 469 Weak-Wind Conditions in Xi'an. Aerosol and Air Quality Research 12, 1261-1268. 